\title{
Diagnostic properties and species composition of maize cobs diseases caused by Fusarium fungi in the Rightbank Forrest-Steppe of Ukraine*
}

\author{
Omeniuk V. \\ National University of Life and Environmental Sciences of Ukraine \\ *Supervisor \\ Doctor of Agricultural Sciences, Professor \\ O.F. Antonenko
}

The purpose. Diagnostic properties investigation and species composition data updating of Fusarium causative agents on maize cobs in the Right-bank Forest-Steppe of Ukraine. Methods. Visual, laboratory, statistical. Results. The article presents the results of experimental studies on the diagnostic features, species composition, dominant pathogens of maize cobs rots caused by Fusarium fungi. Conclusions. The main part of infected maize cobs mycobiota belong to Fusarium fungi genus, which varied over the years in range of $35.9-36.9 \%$. The most common species were: Fusarium verticillioides and Fusarium graminearum. Bibliogr.: 11 titles.

Key words: fusarium, maize cobs, symptoms, species composition, mycobiota.

Fusarium ear rots of maize are among of the most common in all regions of its cultivation [1]. Disease incidence has a significant impact on food and feed safety of products, as most fusarium pathogens produce various types of mycotoxins that have mutagenic and carcinogenic effects $[6,7,10]$.

Diverse types of Fusarium ear rots displaying cause major pathogens such as Fusarium verticillioides (Sacc.) Nirenberg, syn. F. moniliforme J. Sheld. (teleomorfa - Gibberella fujikuroi) and F. graminearumSchwabe (teleomorfa - Gibberella zeae (Schweinitz) Petch) [1].

The main infection period of fusarium is the period from the grain formation up to milk-wax ripeness. Agroclimatic conditions during the growing season determine dominance of certain or similar agents. The infection penetration to ear, in addition to the conidia on silk channels with the wind or rain, contribute to damage by caterpillars of leaf-eating maize pests $[3,5,10]$.

Fusarium immune varieties and hybrids of corn are currently absent nowadays. There are only differences in plants resistance degree to pathogens $[8,9]$. Therefore, for the integrated maize protection, studying of all aspects of the fusarium era rot symptoms and its causes is a very urgent task.

The aim was to study the diagnostic features and species composition of Fusarium pathogens of maize ears in the Right-Bank Forest-Steppe of Ukraine.

Materials and methods of research.

The research of fusarium symptoms was carried out through the maize cobs visual inspection of separate ripeness groups selected on the "Experimental field" of plant pathology department of the NUL\&ES of Ukraine at Agronomichna Doslidna Stanciya during 2015-2016. Laboratory research was conducted in the "Problem research laboratory of Mycology and plant pathology" of the NUL\&ES of Ukraine using macro, microscopic and biological (wet cell) methods [4]. To stimulate pathogens development on affected maize ears, they were placed in desiccators at $100 \%$ humidity and incubated in thermostat at a temperature of $22{ }^{\circ} \mathrm{C}$. To identify fungi from the affected grains, they were removed from pure culture by growing on potato-glucose agar (PGA) [2].

\section{Research results and their discussion.}

Selected samples monitoring and analysis showed that in the researching conditions, cobs infection with fusarium occurred in diverse ways. 
Under favorable conditions, the infection of the pathogen, falling on ears' silk channels with the wind or rain, penetrated to ear and affected grains, depending on the silk channels density and location.

Diseased cobs were characterized by diverse types and depended on boots' density and its closure to the maize ear. Observed a small white plaque of mycelium, mostly between grains or defeat in the form of starburst, which was a reflection of damaged boots of the swath. Grains affected by fusarium, easily crumbled during ear pouring. In some years, the combination of high humidity and daily temperature above $20^{\circ} \mathrm{C}$ in the period from the grain formation up to full ripeness has created favorable conditions for increasing mycelium density with a pink tinge in fusarium damaged areas. All cobs, damaged by pests' caterpillars, were tightly covered with mycelium of the fungus in damaged areas. During maize dead-ripe stage Fusarium settled cobs with mold fungi from the genus Penicillium Link.

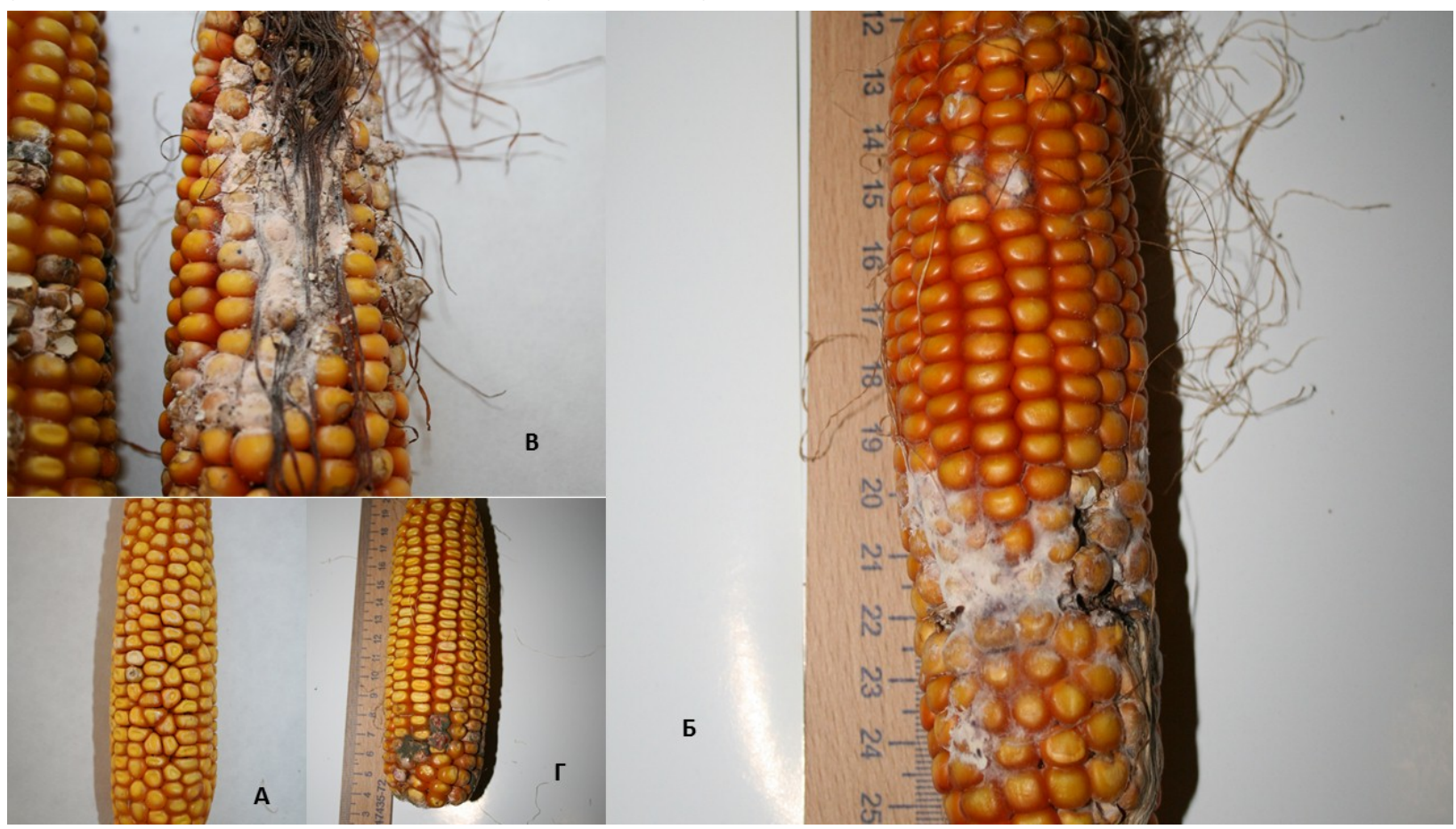

Fig. 1. Diagnostic signs of fusarium on maize ears: a - defeated grains with starburst symptoms; $B$ dense fusarium spew in favorable conditions; 8 - fusarium in areas damaged by pests' caterpillars; $g$ overgrown of ears infected with fusarium pathogens by Penicillium fungi

We also found atypical cases of joint ears' lesions with Fusarium and boil smut (Fig. 2).

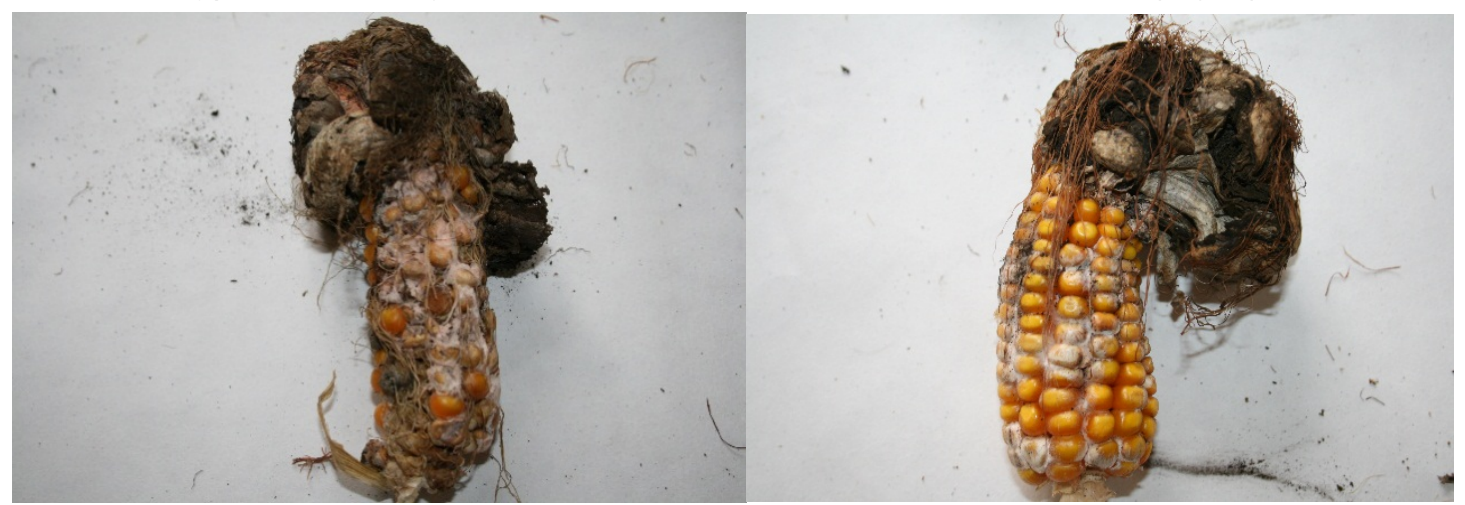

Fig. 2. Symptoms of compatible lesions on maize cobs caused by Fusarium and Ustilago pathogens

Subsequently, under favorable conditions for disease development, in areas already damaged by Fusarium fungi, settled saprophytic Penicillium. Grains, affected by penicillium fungi were covered with gray-green or gray-blue bloom. 
We have analyzed the species composition of fungi, isolated from infected maize cobs of separate ripeness groups. Studies' results of species composition showed that Fusarium fungi occupy a dominant position in micromycetes frequency extraction that ranged over years within 35,9-36,9\% in 2015-2016 respectively Frequency occurrence of Penicillium fungi ranged between 4,9-9,8\% of other species - 9,4$13,6 \%$ respectively in research years (Table 2 ).

Table 1. Micromycetes species composition, isolated from affected maize cobs into full-wax ripeness phase (took from hybrids of different ripeness groups in conditions of the "Experimental field" of the plant pathology department at Agronomichna Doslidna Stanciya) in 2015-2016.

\begin{tabular}{|l|c|c|c|c|c|c|c|c|}
\hline \multirow{2}{*}{ Micromycetes species } & \multicolumn{6}{|c|}{ Separation frequency, \% } \\
\cline { 2 - 10 } & \multicolumn{2}{|c|}{ Early-season } & \multicolumn{2}{|c|}{ Middle-early } & \multicolumn{2}{|c|}{ Mid-season } & \multicolumn{2}{c}{ Middle-late } \\
\cline { 2 - 10 } & 2015 & 2016 & 2015 & 2016 & 2015 & 2016 & 2015 & 2016 \\
\hline F.verticillioides & 15,6 & 22,2 & 17,0 & 21,7 & 18,7 & 19,8 & 23,1 & 28,4 \\
\hline F. graminearum & 6,6 & 11,3 & 6,1 & 5,1 & 6,8 & 9,5 & 12,9 & 7,4 \\
\hline F. oxysporum & 6,3 & 3,5 & 3,4 & 4,5 & 3,4 & 5,8 & 5,6 & 3,1 \\
\hline F. sporotrichioides & 1,2 & 2,3 & 3,7 & 1,6 & 2,6 & 0 & 0 & 1,3 \\
\hline Penicillium spp. & 8,1 & 13,4 & 3,0 & 6,5 & 2,1 & 8,9 & 6,4 & 10,3 \\
\hline Others & 2,9 & 16,8 & 6,4 & 1,8 & 16,1 & 15,2 & 12,0 & 20,6 \\
\hline
\end{tabular}

The main segment of Fusarium fungi held the following species: F.verticillioides, F. graminearum, F. oxysporum, F. sporotrichioides. The frequency extraction varied from 1,2 to $28,4 \%$ in different research years. Found that during field research conducted $F$. verticillioides more often met on cobs of mediumlate maize hybrids. Its maximum frequency was $23,1-28,4 \%$ from total number of this species. Other Fusarium species number in maize full ripeness phase was ranged in $11,7-18,5 \%$. To a lesser extent withdrawn species F. graminearum (7,4-12,9\%), F. oxysporum (3,1-5,6\%), F. sporotrichioides $(1,3 \%)$. Early-season maize hybrids had the lowest rates of defeated cobs by fusarium fungi. Penicillium fungi were associated as saprophytic species, their frequency varied within the limits of fusarium micromycetes frequency.

Several pathogens that had very low incidence were also extracted, which why they were not identified.

\section{Conclusions}

The main ways of Fusarium pathogens penetration to the maize ears were determined: through tissues damaged by insects, fungus spores entering by wind or rain on maize silk channels, with subsequent fungus germination up to the grains.

As a result of the conducted researchings diagnostic signs of fusarium ear rots have been established. Thus, fusarium pathogens parasitizing on maize ears leads to the appearance of different intensity symptoms: light plaque on grains in starburst form or dense overgrowth mycelium on grains, depending on the place and method of infection penetration.

Mycobiota main segment of affected corn ears were Fusarium fungi, which varied over years within $35,9-36,9 \%$. The most common species were Fusarium verticillioides and Fusarium graminearum.

\section{References}

1. Markov I. L. Dovidnyk iz zakhystu pol'ovykh kul'tur vid khvorob ta shkidnykiv: navchal'no-naukove vyrobnyche vydannya / I. L. Markov, M. B. Ruban. - K.: TOV "Kompaniya "Yunivest Media", 2014. - 384 s.

2. Hrysenko H.V., Dudka E.L. Metody fytopatolohycheskykh yssledovanyy po kukuruze. Dnepropetrovsk, 1980, - $63 \mathrm{~s}$. 
3. Yvashchenko V.H., Sotchenko E.F. Fuzaryoz pochatkov kukuruzy v Stavropol'skom krae: étyolohyya bolezny, sortoustoychyvost' // Mater, nauchno-prakt. konf." Selektsyya, semenovodstvo, proyzvodstvo zerna kukuruzy", Pyatyhorsk, -2002, -S., 157-164.

4. Metody éksperymental'noy mykolohy / Y. A. Dudka, S. P. Vasser, Y.A. Éllanskaya [y dr.]; Pod red. V. Y. Bylay. - K.: Nauk. dumka, 1982. $-452 \mathrm{~s}$.

5. Yvashchenko, V.H. Bolezny kukuruzy fuzaryoznoy étyolohyy: osnovnye prychyny y sledstvyya / V.H.Yvashchenko // Vestnyk zashchyty rastenyy, SPb., 2012. N 4. S.3-19.

6. Schaafsma, A.W. Analysis of Fusarium toxins in maize and wheat using thin layer chromatography / A.W. Schaafsma, R.W. Nicol, M.E. Savard, R.C. Sinha, L.M. Reid, G. Rottinghaus // Mycopathologia. 1998. -. Issue 142 - P. 107-113. doi: 10.1080/02652030410001670175

7. Lepom, P. Occurence of fusarium species and their mycotoxins in maize / P. Lepom, K.O Baath // Arch. Anum. Nutrition. - 1988. - Vol. 38, Issue 9 - P. 817 - 823. doi: 10.1080/19393210802236927

8. Mesterházy, Á. Breeding for resistance to ear rots caused by Fusarium spp. in maize- a review / Á. Mesterházy, M. Lemmens, L.M. Reid // Plant Breed. -2012. - Issue 131, P. 1-19 doi:10.1111/j.14390523.2011.01936.x

9. Balint-Kurti PJ, Johal GS (2009). Maize Disease Resistance. (eds.), Handbook of Maize: Its Biology, 229 doi: 10.1007/978-0-387-79418-1-12.

10. Clements, M.J. Evaluation of inoculation techniques for Fusarium ear rot and fumonisin contamination of corn / M.J. Clements, C.E. Kleinschmidt, C.M. Maragos, J.K. Pataky, D.G. White // Plant Disease, 2003, Vol. 87, Issue 2, P. 147-153.doi: 10.1094/PDIS.2003.87.2.147. 